\title{
EVĚ MASNEROVÉ K DEVADESÁTINÁM
}

\author{
Mgr. PETRA DIESTLEROVÁ, \\ REDAKTORKA A PŘEKLADATELKA
}

S docentkou Evou Masnerovou jsem se seznámila v roce 1990, když jsem nastoupila jako studentka angličtiny a francouzštiny na tehdejší Katedru překladatelství tlumočnictví FF UK. Matně si vzpomínám, že v prvním ročníku učila takové ty nevděčné povinné kurzy jako Dějiny a kultura anglicky mluvících zemí, ale už ve druhém ročníku jsem se drze vetřela na její volitelný seminář literárního překladu. Ten byl sice určený pro ročníky vyšší, se specializací na překlad, ale patrně jsem ji udolala svým bezmezným nadšením.

A udělala jsem dobře - právě tenhle seminář mi dal pro moji budoucí práci z celého studia nejvíc. Ukázalo se, že Eva Masnerová je výborný pedagog a také vynikající praktik. Ten malý kroužek zájemců o literární překlad z katedry obecně považované spíše za tlumočnický institut, který se na semináři scházel každý týden, školila v dovednostech nezbytných pro překladatelskou praxi.

Naučila nás vytrvalosti. Dodat na každý seminář přeložený text, at už se do cesty staví zkoušky, kolejní večírky, nebo přivýdělky doprovodným tlumočením.

Naučila nás pečlivosti. Zkoumat každou větu, každý př́iznakový výraz, každý obrat, který by mohl být citát (když to vypadá jako citát, tak obvykle je, a v př́padě anglické literatury obvykle ze Shakespeara, z Bible, $\mathrm{z}$ Alenky v ř́ši divů nebo z Roberta Burnse, v tomto pořadí. A v předinternetových dobách nebylo to dohledávání zrovna jednoduché).

Naučila nás pracovat s jazykovými prostředky. Co je ustálené spojení, jak srozumitelně naložit $s$ reáliemi, a především jak rozpoznat stylovou rovinu originálu a jak ji vystihnout tím, co má čeština $k$ dispozici. A také že ty klamně jednoduché věci bývají na překlad obvykle nejtěžší. ( $Z$ dob před nástupem počítačů se mi bohužel pokusné překlady nedochovaly, ale pamatuju si, že jsme v rámci semináře překládali např́klad Hemingwayovu povídku Indian Camp - zkuste si to a pochopíte, co mám na mysli.)

A taky nás naučila základy redakční praxe, když nás žádala, abychom si svoje překlady redigovali navzájem. Mimořádně cenná zkušenost, která v nás rozvíjela schopnost obhájit svoje řešení, a pokud jsme měli výhrady $\mathrm{k}$ tomu, jak s textem naložil kolega, vedla nás $\mathrm{k}$ tomu, abychom přicházeli s variantami, které jsme považovali za lepší, a dokázali si je zdůvodnit. A držela se zpátky: měla nekonečnou trpělivost s našimi neobratnými či zbrklými nápady i s přeceňováním vlastních sil; úpravy doporučovala vlídně, nikdy nikoho nezesměšnila, neprosazovala vlastní názor a myslím, že to nejdůležitější, co nám předala, byl respekt $\mathrm{k}$ sobě navzájem a především k originálnímu textu.

Teprve po škole, v době, kdy jsem už pracovala v nakladatelství a kdy jsme se se spolu čas od času scházely v jejím vinohradském bytě nad chlebićcy a lahví vína, jsem zjistila, 
že má za sebou víc než dvacet let redakční práce v nakladatelství Odeon, kde působila v redakci anglo-germánské literatury od jeho vzniku až do roku 1975. Spolupracovala s takovými překladateli, jako byli Aloys Skoumal, František Vrba nebo Jan Zábrana. Redakčně jí prošly rukama a očima mnohé z významných titulů anglické a americké literatury, které v Odeonu vycházely.

Sama začala překládat až v době, kdy už měla rozsáhlé zkušenosti s redakční prací, první knižní překlad jí vyšel v roce 1966 (novela Saula Bellowa Ani den!) a překladům se soustavněji věnovala teprve po odchodu z nakladatelství. A přesto je výčet jejích knižních překladů působivý; jsou v něm autoři jako Stephen Crane, Jack London, Eudora Weltyová nebo Michael Ondaatje. Za překlad románu Andrého Brinka Okamžik ve větru získala i překladatelské ocenění.

A překládala i poté, co odešla v roce 1994 z fakulty do důchodu. Dál sledovala anglicky psanou literaturu a doporučovala mi do nakladatelství zajímavé knihy, které se jí dostaly do rukou. A i v době, kdy už ze zdravotních důvodů překládat přestala, nadále se zájmem sledovala, co z anglické a americké literatury vychází.

Ale nejzajímavější byly vždycky naše rozhovory o procesu překládání, při nichž jsme kromě různých jazykových záludností probíraly i otázky jako: „je tř̌eba číst poslední verzi překladu na papíre, a ne v počítači?" (rozhodně ano), „pomáhá čtení hotového překladu nahlas?“ (jak komu), „dá se něco dělat proti bolavým zádům?“" (chodit). A také o redakční praxi - ačkoli se od dob odeonského působení Evy Masnerové hodně proměnila, úsilí o vydávání zajímavých a hodnotných knih zůstalo v určitých rysech stejně namáhavé, byt ze zcela jiných důvodů. A když jsme si vyměňovaly pracovní historky, nemohla jsem se vždycky zbavit dojmu, že jistá paralela by tu byla.

Připadá mi neuvěřitelné, že je Evě Masnerové devadesát let. Vždyt je to docela nedávno, co jsem se u ní doma, v tom tichém, úpravném bytě se starožitnou lednicí, setkala s její téměř stoletou maminkou. Ale asi to tak bude. Vždyt’ ona jako mladá redaktorka spolupracovala s E. A. Saudkem! A ačkoli ji zdravotní problémy v posledních letech přiměly uchýlit se k rodině do Hradce Králové, takže se už nevídáme, pořád je to pro mě jeden z nejlaskavějších lidí a největších odborníků, které znám. Někdo, kdo má bez jakýchkoli postranních úmyslů rád literaturu, k překladu přistupuje s hlubokou svědomitostí a váží si psaného slova. 